\title{
(2) Reflections on leadership in the time of COVID-19
}

\section{OPEN ACCESS}

Education Institute, Cleveland Clinic, Cleveland, OH, USA

\section{Correspondence to}

Dr James K Stoller, Education, Cleveland Clinic, Cleveland, $\mathrm{OH}$ 44195, USA; STOLLEJ@ccf.org

Received 28 March 2020 Revised 1 April 2020 Accepted 1 April 2020 Published Online First 7 April 2020
D Check for updates

(c) Author(s) (or their employer(s)) 2020. Re-use permitted under CC BY-NC. No commercial re-use. See rights and permissions. Published by BMJ.

To cite: Stoller JK. BMJ Leader 2020:4:77-79.
The COVID-19 pandemic, even as we are in its early phase, invites reflection on best leadership practices. As hospitals and providers pivot to respond, the pandemic spotlights leadership in healthcare. What is working as we all collectively combat this global viral scourge? The impetus to analyse leadership practices especially now comes from the adage that 'a crisis is a terrible thing to waste'. ${ }^{1}$ The danger of COVID-19 is self-evident and is already all too apparent around the world. At this writing today (1 April 2020), 873008 individuals have been infected worldwide and 43275 have died. ${ }^{2}$ In addition to the scientific opportunities to better understand the virus, its epidemiology, and strategies to prevent and cure COVID-19 disease, there is a clear opportunity to reflect on how to lead in healthcare through a crisis, to catalogue best practices, and to cascade these leadership practices broadly.

Even as we are in approaching the surge of the pandemic - in my community, on day 10 of a modelled course that predicts a surge approximately 40 days from now, there are already many lessons on leadership-extraordinary actions from 'big L' leaders-those with titled organisational responsibility as well as from 'little l' leadersindividuals without formal leadership titles whose leadership emerges organically. Indeed, a crisis such as this tests available models and hypotheses about leadership.

In cataloguing some best practices that I have witnessed at my institution-the Cleveland Clinic, I will try to articulate these practices and frame them through the lens of extant leadership models. The model by Kouzes and Posner ${ }^{3}$ of five leadership commitments-challenging the process, inspiring a shared vision, enabling others to act, modelling the way and encouraging the heart-provides an especially opportune taxonomy. What follows, then, is a catalogue of leadership practices, an annotation of each with specific examples, and a reflection of how these specific behaviours invoke or challenge existing leadership concepts.

\section{BE PROACTIVE}

Proactivity-anticipating events with contingency plans-has been a critical leadership competency in the coronavirus pandemic. Two kinds of proactivity seem evident-proactivity before the crisis hits and proactivity once the crisis is under way. Indeed, the critical relevance of proactivity has been evident both in its presence and in it is absence. The urgent need to catch up on testing capability in the USA and the potential insufficiency of the supply of personal protective equipment provide examples of the consequences of inaction.
As a favourable example of proactivity before the crisis, the New York Times on 20 March 2020 discusses modelling for a viral pandemic that was undertaken in 2019 by the US Department of Health and Human Services. The model forebode that within 48 days, a viral pandemic would sicken 110 million Americans, hospitalise 7.7 million and kill 586000 . Such anticipatory behaviour, ideally coupled with commensurate action, is key to understanding the people, roles and resources that are needed when a crisis actually befalls us. As discussed below, the coupling with quick action is key, as modelling without action is a hollow exercise.

Proactivity during the crisis regards real-time, dynamic modelling. Based on the expected events, what is the challenge that will materialise tomorrow, next week and next month? From the earliest signal of disease, laboratory medicine colleagues at my institution were developing testing capability for COVID-19. The result is that as of 20 March 2020, roughly two-thirds of all the positive tests in the US state of Ohio were performed at my institution, where local testing capability was developed early. As another example, medical students, respiratory therapists, intensivists and biomedical engineering colleagues at the Cleveland Clinic are currently advancing designs for a rapid production ventilator in anticipation of a need for ventilators that will exceed supply should a surge occur. Also, in the spirit of 'little l' leadership that can be so impactful, medical students in the Cleveland Clinic Lerner College of Medicine have launched an online repository to identify volunteer activities to help busy interns, residents and fellows. Proactivity abounds. Leadership is occurring diffusely, both by those with leadership titles and those without.

Proactivity is captured in the Kouzes and Posner leadership commitment of 'challenging the process'. The centrality of seeing the current state-a projected shortage of equipment and personal protective equipment, developing models with contingencies and, most importantly, using these predictions to drive action has been underscored by the coronavirus pandemic.

\section{CLARIFY GOVERNANCE FOR THE CRISIS}

Crises test the adequacy of existing governance structures and also require deployment of new ad hoc roles. For example, in the coronavirus crisis, the primacy of supply chain and sourcing personal protective equipment from novel sources, like the paint and construction industries, has become evident as we plan for and ready ourselves for the surge of affected patients. Development of an 'incident command' centre which convenes key leaders regularly, makes real-time decisions based on harvesting the group's wisdom, and cascades 
awareness of these decisions broadly is a critical step. Communicating the structure and membership of this incident command team has been an institutional priority. The emphasis on how to organise the institutional response and how to cascade information bespeaks a commitment to 'inspiring a shared vision' and to 'enabling others to act'. The governance structure gives people the latitude to innovate locally and the mandate to share their activities and ideas with the critical incident team.

\section{ACT...QUICKLY}

Quick implementation during a crisis is paramount. Forming an incident command centre reflects awareness that decisions will need to be made quickly and provides organisational infrastructure to do so. Also, the aforementioned example of developing COVID-19 test capability locally at a time when national capacity to test was stalled underscores the importance and value of acting quickly.

Of course, quick action is underpinned by a sense of urgency, which underlies Kouzes and Posner's emphasis on 'challenging the process'. In the case of coronavirus, there has generally been very little need to communicate urgency, as urgency is widely evident in the daily worldwide tally of affected individuals and associated deaths. ${ }^{2}$ At the same time, the fact that college students were still actively convening on beaches to party during spring break on 20 March 2020 reminds us that one can never overcommunicate urgency and that communication must be tailored to the audience. New emphasis is being given to data that young people are not exempt from the risks of serious illness due to COVID-19.

Similarly, an ineluctable consequence of acting quickly is making mistakes. Wisdom from Voltaire that 'The perfect is the enemy of the good' and from Confucius that 'Better a diamond with a flaw than a pebble without ${ }^{4}$ is central to being able to act quickly. Leaders must (and, at the Cleveland Clinic) have amply acknowledged fallibility and the inevitability of making mistakes in our response to coronavirus. At the same time, these leaders have reaffirmed that any mistakes will be made in service of the organisation's mission-'better care of the sick, investigation of their problems, and more teaching of those who serve' and in the current coronavirus crisis, caring for our patients and protecting our fellow caregivers. Furthermore, creating psychological safety ${ }^{5}$ is paramount in a crisis because the event calls on harvesting wisdom from every part of the organisation and, indeed, the world. Leaders' acknowledging their own fallibility in this effort helps create psychological safety, as does leaders' acknowledging others' efforts, even if incompletely successful. As has happened at my institution, when leaders acknowledge that in moving quickly, we will naturally make some mistakes, change course repeatedly and revise our thinking, they create space for colleagues to 'experiment, take risks, and learn from the accompanying mistakes'. ${ }^{3}$ Again, this validates the centrality of having psychological safety and of 'challenging the process'. Also embedded in acting quickly is the leadership commitment of 'enabling others to act'.

\section{COMMUNICATE ACTIVELY}

A successful response to a crisis is the ultimate team effort because all members of the team must be aligned in service of a common goal. Communication is a critical part of achieving the needed alignment. In the context of George Bernard Shaw's admonition that 'the single biggest problem in communication is the illusion that it has taken place', ${ }^{6}$ communication must be frequent, iterative, and must use multiple dissemination media.
Virtual meetings to assure communication have ramped up quickly at my institution, with twice daily calls for the command centre, among institute chairpersons, and the executive team. In addition, information is being cascaded to all stakeholder audiences through daily podcasts, emails, and so on. Videos of the CEO, Dr Mihaljevic, communicating with all 66000 caregivers are regularly posted. Indeed, communication since the very beginning of our planning (on 21 January 2020) has been an absolute priority in service of aligning caregivers and, through forthrightness and compulsive and thorough planning, assuaging anxiety by providing direction about how we will cope and prevail together. The primacy of acting in a synchronised, aligned fashion reflects the very origins of the Cleveland Clinic, which was forged in 1921 in the aftermath of World War I around the concept of 'acting as a unit'. In communicating today, leaders are able to connect our current efforts with our deep-seated culture and the organisational DNA.

Indeed, communication is needed to 'inspire a shared vision'.

\section{BE BOTH REALISTIC AND OPTIMISTIC}

F Scott Fitzgerald's quote that 'The test of a first-rate intelligence is the ability to hold two opposed ideas in the mind at the same time and still retain the ability to function ${ }^{, 7}$ is especially germane here. Leadership in a crisis requires both framing the challenge ahead while profusely acknowledging the contributions that have been made to date and optimistically capturing the reality that we will ultimately emerge from the crisis back to a state of normality. As an example, consider Winston Churchill's famous 'we shall fight on the beaches' speech to the British people in the throes of World War II and London bombings. Churchill amply acknowledged the formidable current challenge while articulating the resolve that ultimately allowed the UK and the allies to prevail. Churchill was truly 'encouraging the heart'.

Leadership communications at the Cleveland Clinic are anchored in realism that coronavirus poses an existential challenge while coupled with optimism-exemplified by sharing specific stories-that our talent, commitment and organisational culture will assure ultimate success. Even when, as now, we are just approaching the eye of the storm, optimism and acknowledgement of colleagues' contributions to date galvanises people's commitment and provides stamina for the long haul.

That leaders demonstrate optimism in their demeanour and behaviours is also key. Embodying the principle of 'modelling the way', colleagues look to leaders' affect to guide their responses. As they see clinician leaders on the front line of clinical care, their resolve to pitch in increases. This opportunity underscores a major advantage of a physician leadership model in which leaders engage in active clinical practice, perhaps especially in times of pressing need as now. ${ }^{8}$

Overall, a crisis heightens the need for great leadership and underscores needed leadership competencies, both through success in their presence and through failure in their absence. Along with specific leadership practices that may hold value to others as they navigate the current coronavirus pandemic or the next challenge, this reflection invokes the five leadership competencies articulated by Kouzes and Posner ${ }^{3}$ as well as the primacy of creating psychological safety. ${ }^{5}$

Contributors This is an original commentary of which JKS is the sole author. The paper is being exclusively submitted for consideration to publish in BMJ Leadership.

Funding The authors have not declared a specific grant for this research from any funding agency in the public, commercial or not-for-profit sectors.

Competing interests None declared. 
Patient consent for publication Not required.

Provenance and peer review Not commissioned; externally peer reviewed.

Open access This is an open access article distributed in accordance with the Creative Commons Attribution Non Commercial (CC BY-NC 4.0) license, which permits others to distribute, remix, adapt, build upon this work non-commercially, and license their derivative works on different terms, provided the original work is properly cited, appropriate credit is given, any changes made indicated, and the use is non-commercial. See: http://creativecommons.org/licenses/by-nc/4.0/.

\section{REFERENCES}

1 Romer P. Available: https://www.nytimes.com/2009/08/02/magazine/02FOBonlanguage-t.html
2 . Available: www. Worldometers.info/coronavirus/ [Accessed 20 Mar 2020].

3 Kouzes J, Posner B. The leadership challenge. 5th edn. Wiley, 2012.

4 . Available: https://www.entrepreneur.cpm/article/249676 [Accessed 20 Mar 2020].

5 Edmondson AC. The Fearless organization: creating psychologic safety in the workplace for learning, innovation, and growth. Harvard Business School. John Wiley and Sons, 2019.

6 . Available: https://www.visualworkplace.com/2016/06/01/the-single-biggestproblem-in-communication-is-the-illusion-that-it-has-taken-place [Accessed $20 \mathrm{Mar}$ 2020].

7 Scott Fitzgerald F. The crack-up, 1945.

8 Stoller JK. The Cleveland clinic: a distinctive model of American medicine. Ann Transl Med 2013. 